\title{
Potential of caveolae in the therapy of cardiovascular and neurological diseases
}

\author{
Gemma Navarro ${ }^{1}$, Dasiel O. Borroto-Escuela ${ }^{2}$, Kjell Fuxe $^{2 \dagger}$ and Rafael Franco ${ }^{1 * t}$ \\ ${ }^{1}$ Departament de Bioquímica i Biologia Molecular, Facultat de Biologia, Universitat de Barcelona, Barcelona, Spain \\ 2 Department of Neuroscience, Karolinska Institutet, Stockholm, Sweden
}

\author{
Edited by: \\ Annemiek Van Spriel, Radboud \\ Institute for Molecular Life \\ Sciences, Netherlands \\ Reviewed by: \\ Alex M. Dopico, The University of \\ Tennessee Health Science Center, \\ USA \\ Cristina Moreno Vadillo, Maastricht \\ University, Netherlands \\ *Correspondence: \\ Rafael Franco, Departament de \\ Bioquímica i Biologia Molecular, \\ Facultat de Biologia, Diagonal 645, \\ 08028 Barcelona, Spain \\ e-mail: rfranco@ub.edu; \\ rfranco123@gmail.com \\ ${ }^{\dagger}$ These authors have contributed \\ equally to this work.
}

\begin{abstract}
Caveolae are membrane micro-domains enriched in cholesterol, sphingolipids and caveolins, which are transmembrane proteins with a hairpin-like structure. Caveolae participate in receptor-mediated trafficking of cell surface receptors and receptor-mediated signaling. Furthermore, caveolae participate in clathrin-independent endocytosis of membrane receptors. On the one hand, caveolins are involved in vascular and cardiac dysfunction. Also, neurological abnormalities in caveolin-1 knockout mice and a link between caveolin-1 gene haplotypes and neurodegenerative diseases have been reported. The aim of this article is to present the rationale for considering caveolae as potential targets in cardiovascular and neurological diseases.
\end{abstract}

Keywords: arrhythmia, dementia, gene therapy, GPCR, ischemia reperfusion, neurodegeneration, Parkinson's disease, stem cell

\section{INTRODUCTION}

Caveolins are a family of proteins with a hairpin-like structure. This structure is necessary to form unique membrane microdomains known as caveolae. To our knowledge Yamada (1955) first identified caveolae in gallbladder epithelium. The author observed: "The free cell surface between microvilli shows larger cave-like depressions, likewise representing caveolae intracellulares, containing a dense material." Twenty years later, Dulhunty and Franzini-Armstrong (1975) provided a detailed account of the appearance of caveolae using freeze-fracture replicas of the cell surface membrane of frog skeletal muscles. They defined the structure as: "elliptical invaginations of the plasmalemma which open to the outside by a narrow 'neck' of approximately $20 \mathrm{~nm}$." Rothberg et al. (1992) identified and named as caveolin the key component in such membrane micro-domains. Caveolins are a family of proteins with similar structure and, to date, three members have been identified. The first member, VIP21-caveolin or caveolin-1, is widely expressed in tissues, especially in adipocytes, fibroblasts, epithelial cells and vascular endothelial cells; caveolin2 interacts with and is co-expressed with caveolin-1; and, Mcaveolin or caveolin-3, is mainly expressed in striated (skeletal and smooth) muscle myocytes (Scherer et al., 1996; Tang et al., 1996; Way and Parton, 1996; see Gratton et al., 2004 and Gazzerro et al., 2010 for review). Caveolae are enriched in cholesterol and sphingolipids (Severs, 1981; Rothberg et al., 1990; Parton, 1994) and the high content in cholesterol allows manipulating the

Abbreviations: GPCR, G-protein-coupled receptor; GRK, G protein-coupled receptor kinases. system using sterol-binding agents (e.g., methyl- $\beta$-cyclodextrin or filipin). These compounds have been indeed invaluable to study the physiological role of caveolae. Vertical domains that usually span both cell membrane leaflets and are enriched in cholesterol and sphingolipids are known as lipids rafts. Caveolae are considered lipid rafts in as much as they contain caveolins.

The two most obvious roles of caveolae are to recruit membrane proteins at specific membrane domains and to participate in protein internalization (recently reviewed in Shvets et al., 2014). Also they can regulate numerous enzyme activities, including that of adenylate cyclase (AC), eNitric oxide synthase (eNOS), and several kinases and serine/threonine phosphatases (Toya et al., 1998; Carman et al., 1999; Razani and Lisanti, 2001; Hnasko and Lisanti, 2003). Hence, caveolins/caveolae are not just organizers or scaffolds that localize signaling proteins but regulators of important cell events. This perspective article focuses on the therapeutic potential of targeting caveolins/caveolae in cardiovascular and neurological diseases.

\section{CAVEOLAE AND CARDIOVASCULAR DISEASES}

Altered endothelium appears as a common factor in a variety of serious diseases (Berman et al., 1990; Harrison, 1991; Lerman and Burnett, 1992; Quyyumi, 1998; Vincent et al., 2011; Salmon and Satchell, 2012). Caveolins and caveolae are very relevant to maintain the endothelial cell membrane integrity in both structure and function (Williams and Lisanti, 2004; Yuan and Rigor, 2010). Atherosclerosis, a frequent disease in Western societies, is 
due to deposition of cholesterol-rich lipoproteins in the endothelium of blood vessels. Transcytosis, which is a vesicle-mediated mechanism of transcellular transport of molecules, is very important to remove lipid deposits and to avoid endothelial activation and vessel occlusion. Recent evidence shows that caveolin-1 and caveolae are involved in metabolic switching, endothelial transcytosis and regulate vascular inflammation (Pavlides et al., 2014; Shiroto et al., 2014).

Often, heart abnormalities course with abnormal calcium handling, for instance, in atrial fibrillation (Hove-Madsen et al., 2004) and hypertrophy (Gwathmey and Morgan, 1985; Cuneo and Grassi de Gende, 1988). Phospholipase C and hetero-trimeric $\mathrm{Gq}$ proteins regulate intracellular calcium concentrations. In an elegant study Guo et al. (2011) identified Gq proteins in caveolae and reported that adult caveolin-3-containing ventricular cardiomyocytes show oscillating $\mathrm{Ca}^{2+}$ waves that are extinguished by blocking the interaction between caveolin- 3 and the $\alpha$ subunit of Gq proteins. Therefore, caveolin-3 is directly involved in regulating contractility and may be a target for heart hypertrophy.

Mutations in the caveolin-1 gene and decreased expression of caveolin-1 have been identified in patients with pulmonary arterial hypertension (Desai, 2012), a disease with high morbidity. Caveolin-1 null mice display a marked reduction in life span due to a combination of cardiac hypertrophy, pulmonary fibrosis and pulmonary hypertension (Park et al., 2003). Interestingly, double $\mathrm{KO}$ mice for caveolin-1 and the myocyte-selective subtype, caveolin-3, are viable but display severe cardiomyopathy (Park et al., 2002). Although Feiner et al. (2011) could not demonstrate significantly different levels of caveolin-3 in failing hearts, a significant correlation existed in human failing hearts between levels of caveolin-3 and $\mathrm{Ca}^{2+}$-ATPase, a marker of the heartfailure phenotype. To our knowledge, Fujimoto in (1993) was the first to identify an ion pump $\left(\mathrm{Ca}^{2+}\right)$ in caveolae. Since then several studies have confirmed a link between caveolins/caveolae and ion carriers. In cardiomyocytes the $\mathrm{Na}^{+} / \mathrm{Ca}^{2+}$ exchanger is very important for heart functionality. The exchanger may interact with caveolin-1 but may also form macromolecular complexes with caveolin-3 and annexin A5 (Bossuyt et al., 2002a,b). In left ventricular myocardial samples from human failing hearts the annexin A5-interaction site in the exchanger is not accessible and the interaction between the carrier and caveolin-3 is reduced. The data suggests that caveolin-3-containing structures are relevant for $\mathrm{Ca}^{2+}$ handling in cardiac cells (Camors et al., 2006). The involvement of caveolae in different cardiovascular diseases makes caveolin-based therapeutic approaches an attractive possibility to combat myocardial ischemia, heart failure and pulmonary hypertension (see Fridolfsson and Patel, 2013).

Cumulative evidence in the last decade has shown that key proteins in cardiomyocyte function interact with caveolins. Thus, caveolins not only participate in membrane positioning but also in ion channel regulation. Many ion transporters interact with caveolins and/or are located in caveolae (see Balijepalli and Kamp, 2008, for review). The human inward rectifying voltagegated HERG $\mathrm{K}^{+}$channel (Trudeau et al., 1995) interacts with caveolin-1 and reduces its activity when caveolin is up-regulated (Lin et al., 2008). Cell surface expression and degradation of HERG is also controlled by caveolin-3 via a complex of these two proteins with the Nedd4-2 ubiquitin ligase (Guo et al., 2012) and via dynamin-mediated endocytosis (Massaeli et al., 2010). Caveolin-3 interacts with another $\mathrm{K}^{+}$inward rectifying channel (Kir2.1) whose current densities are affected by mutations in caveolin-3 (Vaidyanathan et al., 2013). Mutations in the cardiac $\mathrm{hNa}(\mathrm{v}) 1.5$ channel lead to cardiac phenotypic manifestations; interestingly, caveolin-3 mutations identified in patients with inherited long-QT syndrome result in enhanced currents via this specific sodium channel (Vatta et al., 2006, see Wilde and Brugada, 2011, for review). Mutations in the caveolin-3 gene are also related to sudden infant death syndrome, with higher risk in carriers with further mutations in the $\mathrm{hNa}(\mathrm{v}) 1.5$ gene (Arnestad et al., 2007; Cronk et al., 2007). Finally, caveolae may regulate ion handling by recruiting ion transporters and regulatory molecules (Yarbrough et al., 2002; Shibata et al., 2006; Palygin et al., 2008). A computer-based investigation supports the possibility that accumulation of ions in caveolae may lead to delayed-repolarization-induced arrhythmias (Besse et al., 2011). It is also of interest that caveolin-3 may be linked to and alters the function of hyperpolarization-activated cyclic nucleotide-gated channel 4, which regulates cardiac pacemaker activity (Ye et al., 2008). Balijepalli and Kamp (2008) provide a detailed account of the role of caveolae in arrhythmogenesis.

\section{CAVEOLAE AND NEUROLOGICAL DISEASES}

As neurological diseases are very diverse we present below a few examples of results that support a link between caveolins/caveolae and the two most prominent neurodegenerative disorders in developed countries: Parkinson's and Alzheimer's diseases.

$\alpha$-synuclein is a protein that often accumulates in the brain of Parkinson's disease patients (Polymeropoulos et al., 1997; Arawaka et al., 1998; Takeda et al., 1998). $\alpha$-synuclein seems to cause neurodegeneration by interacting with signaling proteins and/or altering receptor-mediated signaling pathways. Examples of proteins targeted by $\alpha$-synuclein are protein kinase $C$, extracellular signal-regulated kinase (ERK) and phospholipase D (Ostrerova et al., 1999; Iwata et al., 2001; Ahn et al., 2002). Biochemical studies using $\alpha$-synuclein-overexpressing human neuroblastoma cells show a correlation between altered ERK signaling and deregulation of caveolin-1 expression (Hashimoto et al., 2003). In parkinsonian patients but not in controls, six homozygous haplotypes of the caveolin-1 gene have been identified Darvish et al. (2013). Furthermore, the leucine-rich repeat kinase 2 (LRRK2) is located in the neck of caveolae in a human cell model (Alegre-Abarrategui et al., 2009). Mutations in the gene of this kinase are linked to Parkinson's disease (Di Fonzo et al., 2005; Gilks et al., 2005). Overall, the results establish a link between caveolin-1 and molecular hallmarks of Parkinson's disease.

Alzheimer's disease has two pathological hallmarks: intracellular neurofibrillary tangles, made up of aberrantly phosphorylated tau protein and plaques, made up of amyloidogenic (aberrant) processing of the amyloid precursor protein (APP), that leads to $A ß$ peptide. The enzyme that cleaves APP to give $\mathrm{A} ß$ (BACE-1) physically associates to lipid-raft proteins (Hattori et al., 2006). Caveolin-3 is up-regulated in glial cells surrounding plaques and enhances the amyloidogenic route of APP processing (Nishiyama et al., 1999). Furthermore, caveolins physically 
associate to presenilins (Nishiyama et al., 1999) that are also relevant molecules in the pathophysiology of Alzheimer's disease. Therefore, caveolae were suspected to be involved in processing of APP, a transmembrane protein requiring integrity of cell surface mechanisms for a correct physiological function. The first indication for this view came in 1998 from the identification of the $A B$ peptide in detergent-insoluble compartments (Lee et al., 1998). More recently caveolin-1 knockout mice are considered a nonmutational model for Alzheimer's disease based on the accelerated aging and neurodegeneration phenotype (Head et al., 2010). The mice displayed astrogliosis and increased $A \beta$ and hyperphosphorylated tau and, noteworthy, expression of caveolin-1 in neurons from the animals led to a significant decrease in $A \beta$ expression (Head et al., 2010).

\section{THERAPEUTIC POSSIBILITIES: TARGETING CAVEOLIN EXPRESSION}

Caveolins/caveolae are now considered as therapeutic targets for a variety of diseases. Inhibitors are more frequent than activators as drugs targeting enzymes. Drugs targeting receptors are more often antagonists (blockers) than agonists (activators). Matters in the case of caveolins/caveolae are not as straightforward as caveolins have neither orthosteric binding sites for function regulation nor regulatory sites. To our knowledge, no small molecule targeting caveolins has been developed. Difficulties in targeting this type of membrane proteins likely underlie this lack of drug development and limit the use of caveolins as drug targets. One way to circumvent this issue is the use of anti-caveolin antibodies (Oh and Schnitzer, 1999; Gumbleton et al., 2003). Another limitation is the absence of suitable readouts for caveolin action. In sharp contrast there are highly suitable and high throughput possibilities for both enzymes and receptors. A significant alternative intervention to either increase or decrease caveolin expression would be gene or cell therapy, direct targeting of caveolin using antisense and siRNA approaches, modulation of cellular cholesterol levels or caveolar lipid content and the use of inhibitory peptides derived from caveolin scaffolding domains.

Regulation of cholesterol levels or caveolar lipid content may thus be attempted for therapeutic purposes. The use of statins such as 3-hydroxy-3-methylglutaryl-coenzyme A (HMG-CoA) reductase inhibitors decrease caveolin-1 levels (Kusama et al., 2001), which can involve blockade of the production of mevalonate, an intermediate in isoprenoid and cholesterol synthesis (Kirschmeier et al., 2001). Simvastatin may also alter lipid raft composition (Zhuang et al., 2005).

Despite the fact that gene therapy has not delivered the promised results, new viral vectors may be suitable to target caveolae with efficacy in the affected tissue. This would prevent side effects due to indiscriminate targeting of multiple tissues. Viruses can use caveolae-dependent or -independent mechanisms to enter the cell. One may take advantage of this fact to design therapeutic strategies using viral vectors that target caveolae (see next section). Analogously, polymeric structures may target caveolae and interfere with caveolae-mediated physiological or pathological actions. As an example, polysorbitol-based transporter delivery of small interfering RNA use caveolae for cell entry
(Islam et al., 2012). Dendrimers successful in delivering genes via caveolae (Huang et al., 2014) merit attention for either enhancing or depressing caveolae-mediated events. Similarly, complexes formed by protamine, dextran, and solid lipid nanoparticles may target caveolae after intravenous administration to mice (Delgado et al., 2012).

\section{THERAPEUTIC POSSIBILITIES: FROM CELL THERAPY TO BLOCKADE OF CAVEOLAE-MEDIATED TRAFFIC AND TARGETING OF CAVEOLIN-PROTEIN/RECEPTOR INTERACTIONS}

Cell therapy is providing new hopes for a variety of diseases. Cell therapy using autologous stem cells engineered to express specific caveolins may be considered a further possibility to colonize tissues with caveolins/caveolae-related pathologies. To colonize lungs, Ghaedi et al. (2013) have been successful in developing caveolin-1 expressing alveolar epithelial cells from human induced pluripotent stem (iPS) cells. Similarly, other iPS-derived cells may have the potential to colonize endothelium in different tissues or, alternatively, iPS cells may differentiate into neurons (Chung et al., 2013) or, eventually into cardiomyocytes. To increase safety of cell therapy, generation of tumor-free iPS cell has been recently possible (Phillips, 2014; Zhang et al., 2014).

Caveolins/caveolae may be indirectly targeted by blocking membrane fusion events related to endocytosis. Dynasore, an inhibitor of the GTPase activity of dynamin may prevent the entry into cells of papilloma viruses that require caveolae- and clathrin-mediated endocytosis (Abban et al., 2008). Paramyxoviruses (Sánchez-Felipe et al., 2014) and neurotropic viruses such as Japanese encephalitis virus (Zhu et al., 2012) also use a caveolae and dynamin-dependent mechanism to enter into cells. Therefore, these viruses constitute a basis to design caveolae-targeting vectors.

Skeletal muscle expressing the Pro104Leu mutant of caveolin-3 leads to atrophy, and mice with this mutation serve as a model of limb-girdle muscular dystrophy 1C (Minetti et al., 1998; Galbiati et al., 2000; Hagiwara et al., 2000). The transforming growth factor type I $\beta$ receptor kinase inhibitor, Ki26894, is able to restore both in vitro muscle cell deficiencies and muscle atrophy and weakness displayed by mutant mice (Ohsawa et al., 2012). A similar intervention could be envisaged for restoring cardiomyocyte function in patients with cardiac atrophy.

A further possibility is to modulate proteins located in caveolae to activate caveolae-mediated restorative events. Members of the G-protein-coupled receptor (GPCR) superfamily are a relevant example. GPCRs are targets of approximately $40 \%$ of compounds used in human therapy. Agonist and/or antagonist modulation of their activity can lead to increases or decreases in the expression levels of caveolins. In addition, it seems possible that GPCRs can form heteroreceptor complexes with caveolins. Interactions may modify the pharmacological properties in turn making possible the design of compounds selective for GPCR protomers present in such complexes. Examples of the direct link between caveolae and GPCRs are given in the next section.

Many proteins and receptors (e.g., GPCR) contain putative caveolin binding domains (Couet et al., 1997). For instance, 
caveolin-1 interacting proteins contain the canonical caveolin-1 binding domain, $\phi \mathrm{X} \phi \mathrm{XXXX} \phi$ or $\phi \mathrm{XXXX} \phi \mathrm{XX} \phi$ (where $\phi=\operatorname{Tr}$, Phe or Tyr). In some pathologies, reducing the ability of caveolins to couple to the signaling machinery at the inner plasma membrane may result in an efficacious intervention. For instance, the introduction of synthetic caveolin-scaffolding-domain peptides into cells may inhibit caveolin-protein interactions. In support of this, internalization of the caveolin scaffolding domain may be achieved by fusion of the domain with a 16 -amino acid peptide of the Drosophila antennapedia homeodomain. By this approach platelet activating-factor-induced NO production and microvasculature permeability was reduced in tumor bearing animals (Zhu et al., 2004). It should be noted that neovascularization is required in initial steps of metastatic colonization of tissues and that caveolin-1 regulates metastasis in bladder cancer (Thomas et al., 2011).

Use of indirect caveolin-modulating strategies may also be effective against cardiovascular and neurological diseases. As detailed in the previous and the following sections, the bidirectional relationship that caveolins have with a number of interacting proteins and receptors could be exploited to reexpressing or targeting caveolins for up- and down-regulation. Examples would be targeting some GPCRs. The use of GPCRselective agonist or antagonist, many of which are in current clinical use, may also affect directly (via receptor-caveolin interactions) or indirectly (via second messenger and signal cascade activation, e.g., MAPK) caveolin expression levels. Via activation of some GPCRs we could control or re-program caveolin expression levels to explore therapeutic outcomes in heart and brain.

\section{CAVEOLAE AND GPCRs}

Cumulative evidence points to caveolae and caveolins as important regulators of GPCR traffic and function thus raising therapeutic potential in targeting caveolae or GPCRs in caveolae (see Figure 1). Caveolins form homo-oligomers (Monier et al., 1995; Sargiacomo et al., 1995) and interact with G proteins (Li et al., 1995). GPCRs are not homogeneously distributed on the cell surface and a significant amount of receptors are in caveolae (Ginés et al., 2001). GPCRs may even interact with caveolins (Burgueño et al., 2003, 2004). Even important elements in GPCR-mediated signaling such as $G$ protein-coupled receptor kinases (GRKs) have binding motives for caveolins and the interaction regulates GRK function (Carman et al., 1999). Depending on cell type, and probably on caveolin subtype, GPCR agonists may enrich receptors in caveolae or do the opposite. In fact, agonist-induced activation of adenosine receptors may recruit them into caveolae for caveolaemediated internalization (Ginés et al., 2001; Escriche et al., 2003).

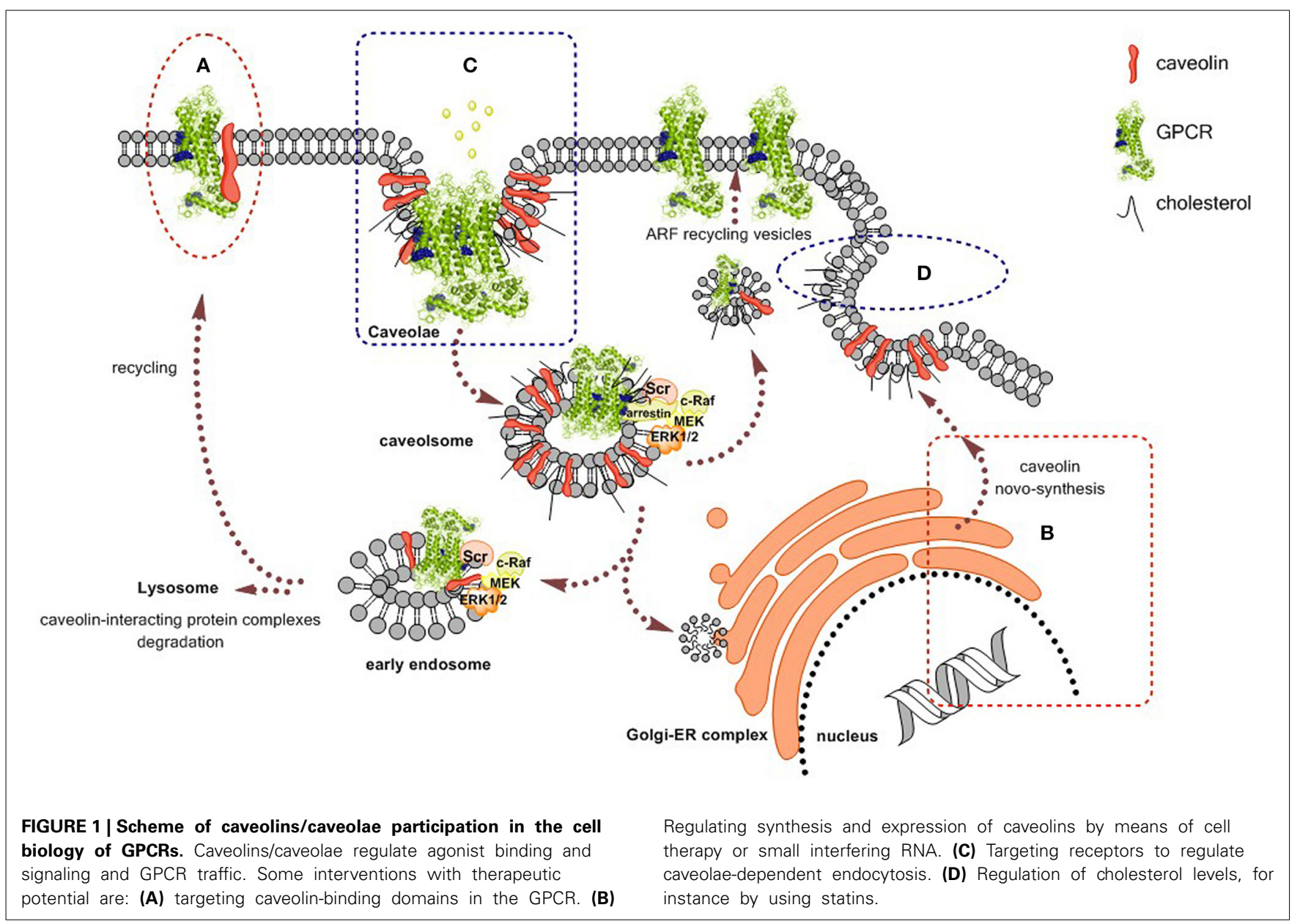


In contrast, in cardiomyocytes, these adenosine receptors are enriched in caveolae until activation leads to translocation out of caveolae (Lasley et al., 2000; Lasley and Smart, 2001). This differential behavior may be taken into account when targeting caveolae via GPCRs.

Specific G-protein-related signaling components are enriched in lipid rafts/caveolae meaning that these structures affect Gprotein-coupling efficacy and signaling selectivity (see Chini and Parenti, 2004 and Insel et al., 2005, for review). An exhaustive review of the reports linking caveolins/caveolae to the biology of GPCRs is out of the scope of the present perspective article. Some few examples will, however, be provided to give a hint of the relevant connections between the receptors and caveolae. Localization of the $\alpha_{1 \mathrm{~A}}$ adrenergic GPCR in lipid rafts restricts their conformation and basal activity while allowing a substantial coupling to the $\mathrm{G}$ protein and a robust signaling upon agonist activation (Lei et al., 2009). Caveolin-2 participates in receptor signaling even in a simple system constituted by human embryonic kidney (HEK-293) cells expressing a GPCR $\left(D_{1}\right)$ for the neurotransmitter dopamine (Yu et al., 2004). Caveolin is also involved in agonist-induced recruitment and internalization of a GPCR for the regulatory molecule adenosine (subtype $1, \mathrm{~A}_{1}$ receptor) (Ginés et al., 2001). In fact, Escriche et al. (2003) provided morphological evidence of caveolae-mediated internalization, endosomal sorting and $\mathrm{A}_{1}$ receptor recycling. Very relevant for caveolae-based drug discovery, Klaasse et al. (2005) reported small-molecule allosteric modulators of adenosine $A_{1}$ GPCRs that affect internalization of the receptor. Adenosine deaminase, also interacts with $\mathrm{A}_{1}$ GPCRs, enhances signaling and appears to be an allosteric modulator of caveolae-mediated receptor internalization (Ginés et al., 2001). Caveolae disruption by cholesterol depletion alters the regulation by adenosine subtype $2\left(\mathrm{~A}_{2 \mathrm{~A}}\right)$ of anion secretion in epithelial cells (Lam et al., 2009). Adenosine $\mathrm{A}_{2 \mathrm{~A}}$ GPCRs are up-regulated in atrial fibrillation and their blockade results in restoring the abnormal calcium handling in cardiomyocytes from patients (Hove-Madsen et al., 2006; Llach et al., 2011). Adenosine $A_{2 A}$ GPCRs may also form homodimers or heteromers with other receptors. The complexes are unique entities with specific signaling properties (Hillion et al., 2002; Canals et al., 2004). Therefore, differential expression of $\mathrm{A}_{2 \mathrm{~A}}$ GPCR monomer/homomers/heteromers in membrane micro-domains is an interesting possibility for altered functional properties that should be further explored. Endothelin subtype B receptor in endothelial cells is mainly present in caveolae and its activation by endothelin leads to rapid caveolae-dependent internalization. It is likely that activation of such receptors present in caveolae leads to rapid caveolae-mediated trafficking (Oh et al., 2012).

The selective advantage of reperfusion after ischemic injury to minimize the consequences of a second ischemic episode has been known for long (see Yellon et al., 1998 for review). From the finding that the increase in extracellular adenosine was helpful in anoxic heart conditions (Jacob and Berne, 1961; Ely and Berne, 1992) several studies have shown that adenosine (Kitakaze et al., 1993; Pelleg, 1993) and other compounds acting on GPCRs (Avkiran and Haworth, 2003; Minguet et al., 2012; Dragasis et al., 2013) regulate heart-ischemia-reperfusion and preconditioning. As reviewed by Stary et al. (2012) caveolins are necessary for ischemic preconditioning. Targeting for instance opioid receptors may help in enhancing the reperfusion benefits. Opioidinduced preconditioning alters the architecture of the myocyte and increases the number of caveolae (Tsutsumi et al., 2010; Stary et al., 2012). The use of knockout animals for caveolin-3 has shown that this protein is essential for in vivo opioid-induced preconditioning (Tsutsumi et al., 2010).

Future work will help on understanding how caveolin-protein and caveolin-GPCR interactions may help in combating cardiovascular and neurological diseases.

\section{ACKNOWLEDGMENTS}

This work has been supported by the Swedish Medical Research Council (62X-00715-50-3), Karolinska Institutets Forskningsstiftelser 2013 and AFA-2014 to KF; by grants from the Swedish Royal Academy of Sciences (Stiftelsen B. von Beskows Fond and Stiftelsen Hierta-Retzius stipendiefond) and Karolinska Institutets Forskningsstiftelser 2013 to Dasiel O. Borroto-Escuela. Dasiel O. Borroto-Escuela belongs to "Academia de Biólogos Cubanos."

\section{REFERENCES}

Abban, C. Y., Bradbury, N. A., and Meneses, P. I. (2008). HPV16 and BPV1 infection can be blocked by the dynamin inhibitor dynasore. Am. J. Ther. 15, 304-311. doi: 10.1097/MJT.0b013e3181754134

Ahn, B. H., Rhim, H., Kim, S. Y., Sung, Y. M., Lee, M. Y., Choi, J. Y., et al. (2002). alpha-Synuclein interacts with phospholipase D isozymes and inhibits pervanadate-induced phospholipase D activation in human embryonic kidney293 cells. J. Biol. Chem. 277, 12334-12342. doi: 10.1074/jbc.M110414200

Alegre-Abarrategui, J., Christian, H., Lufino, M. M., Mutihac, R., Venda, L. L., Ansorge, O., et al. (2009). LRRK2 regulates autophagic activity and localizes to specific membrane microdomains in a novel human genomic reporter cellular model. Hum. Mol. Genet. 18, 4022-4034. doi: 10.1093/hmg/ddp346

Arawaka, S., Saito, Y., Murayama, S., and Mori, H. (1998). Lewy body in neurodegeneration with brain iron accumulation type 1 is immunoreactive for alpha-synuclein. Neurology 51, 887-889. doi: 10.1212/WNL.51.3.887

Arnestad, M., Crotti, L., Rognum, T. O., Insolia, R., Pedrazzini, M., Ferrandi, C., et al. (2007). Prevalence of long-QT syndrome gene variants in sudden infant death syndrome. Circulation 115, 361-367. doi: 10.1161/CIRCULATIONAHA. 106.658021

Avkiran, M., and Haworth, R. S. (2003). Regulatory effects of G protein-coupled receptors on cardiac sarcolemmal $\mathrm{Na}+\mathrm{H}+$ exchanger activity: signalling and significance. Cardiovasc. Res. 57, 942-952. doi: 10.1016/S0008-6363(02)00782-4

Balijepalli, R. C., and Kamp, T. J. (2008). Caveolae, ion channels and cardiac arrhythmias. Prog. Biophys. Mol. Biol. 98, 149-160. doi: 10.1016/j.pbiomolbio. 2009.01.012

Berman, J. S., Beer, D. J., Theodore, A. C., Kornfeld, H., Bernardo, J., and Center, D. M. (1990). Lymphocyte recruitment to the lung. Am. Rev. Respir. Dis. 142, 238-257. doi: 10.1164/ajrccm/142.1.238

Besse, I. M., Mitchell, C. C., Hund, T. J., and Shibata, E. F. (2011). A computational investigation of cardiac caveolae as a source of persistent sodium current. Front. Physiol. 2:87. doi: 10.3389/fphys.2011.00087

Bossuyt, J., Taylor, B. E., James-Kracke, M., and Hale, C. C. (2002a). The cardiac sodium-calcium exchanger associates with caveolin-3. Ann. N.Y. Acad. Sci. 976, 197-204. doi: 10.1111/j.1749-6632.2002.tb04741.x

Bossuyt, J., Taylor, B. E., James-Kracke, M., and Hale, C. C. (2002b). Evidence for cardiac sodium-calcium exchanger association with caveolin-3. FEBS Lett. 511, 113-117. doi: 10.1111/j.1749-6632.2002.tb04741.x

Burgueño, J., Canela, E. I., Mallol, J., Lluis, C., Franco, R., and Ciruela, F. (2004). Mutual regulation between metabotropic glutamate type lalpha receptor and caveolin-proteins: from traffick to constitutive activity. Exp. Cell Res. 300, 23-34. doi: 10.1016/j.yexcr.2004.06.013

Burgueño, J., Enrich, C., Canela, E. I., Mallol, J., Lluis, C., Franco, R., et al. (2003). Metabotropic glutamate type lalpha receptor localizes in 
low-density caveolin-rich plasma membrane fractions. J. Neurochem. 86, 785-791.

Camors, E., Charue, D., Trouvé, P., Monceau, V., Loyer, X., Russo-Marie, F., et al. (2006). Association of annexin A5 with $\mathrm{Na}+/ \mathrm{Ca} 2+$ exchanger and caveolin-3 in non-failing and failing human heart. J. Mol. Cell. Cardiol. 40, 47-55. doi: 10.1016/j.yjmcc.2005.08.009

Canals, M., Burgueño, J., Marcellino, D., Cabello, N., Canela, E. I., Mallol, J., et al. (2004). Homodimerization of adenosine A2A receptors: qualitative and quantitative assessment by fluorescence and bioluminescence energy transfer. $J$. Neurochem. 88, 726-734. doi: 10.1046/j.1471-4159.2003.02200.x

Carman, C. V., Lisanti, M. P., and Benovic, J. L. (1999). Regulation of G proteincoupled receptor kinases by caveolin. J. Biol. Chem. 274, 8858-8864. doi: $10.1074 / \mathrm{jbc} .274 .13 .8858$

Chini, B., and Parenti, M. (2004). G-protein coupled receptors in lipid rafts and caveolae: how, when and why do they go there? J. Mol. Endocrinol. 32, 325-338. doi: 10.1677/jme.0.0320325

Chung, C. Y., Khurana, V., Auluck, P. K., Tardiff, D. F., Mazzulli, J. R., Soldner, F., et al. (2013). Identification and rescue of $\alpha$-synuclein toxicity in Parkinson patient-derived neurons. Science 342, 983-987. doi: 10.1126/science.1245296

Couet, J., Li, S., Okamoto, T., Ikezu, T., and Lisanti, M. P. (1997). Identification of peptide and protein ligands for the caveolin-scaffolding domain. Implications for the interaction of caveolin-with caveolae-associated proteins. J. Biol. Chem. 272, 6525-6533. doi: 10.1074/jbc.272.10.6525

Cronk, L. B., Ye, B., Kaku, T., Tester, D. J., Vatta, M., Makielski, J. C., et al. (2007). Novel mechanism for sudden infant death syndrome: persistent late sodium current secondary to mutations in caveolin-3. Heart Rhythm. 4, 161-166. doi: 10.1016/j.hrthm.2006.11.030

Cuneo, M. E., and Grassi de Gende, A. O. (1988). Cardiac sarcoplasmic reticulum characteristics in hypertrophic hearts from spontaneously hypertensive rats. Basic Res. Cardiol. 83, 286-295. doi: 10.1007/BF01907362

Darvish, H., Heidari, A., Hosseinkhani, S., Movafagh, A., Khaligh, A., Jamshidi, J., et al. (2013). Biased homozygous haplotypes across the human caveolin-1 upstream purine complex in Parkinson's disease. J. Mol. Neurosci. 51, 389-393. doi: 10.1007/s12031-013-0021-9

Delgado, D., Gascón, A. R., Del Pozo-Rodríguez, A., Echevarría, E., Ruiz de Garibay, A. P., Rodríguez, J. M., et al. (2012). Dextran-protamine-solid lipid nanoparticles as a non-viral vector for gene therapy: in vitro characterization and in vivo transfection after intravenous administration to mice. Int. J. Pharm. 425, 35-43. doi: 10.1016/j.ijpharm.2011.12.052

Desai, A. A. (2012). Novel inheritable caveolin-1 mutations in pulmonary arterial hypertension. Circ. Cardiovasc. Genet. 5, 706-707. doi: 10.1161/ CIRCGENETICS.112.965335

Di Fonzo, A., Rohé, C. F., Ferreira, J., Chien, H. F., Vacca, L., Stocchi, F., et al. (2005). Italian parkinson genetics network. A frequent LRRK2 gene mutation associated with autosomal dominant Parkinson's disease. Lancet 365, 412-415. doi: 10.1016/S0140-6736(05)17829-5

Dragasis, S., Bassiakou, E., Iacovidou, N., Papadimitriou, L., Andreas Steen, P., Gulati, A., et al. (2013). The role of opioid receptor agonists in ischemic preconditioning. Eur. J. Pharmacol. 720, 401-408. doi: 10.1016/j.ejphar.2013.10.001

Dulhunty, A. F., and Franzini-Armstrong, C. (1975). The relative contributions of the folds and caveolae to the surface membrane of frog skeletal muscle fibres at different sarcomere lengths. J. Physiol. 250, 513-539.

Ely, S. W., and Berne, R. M. (1992). Protective effects of adenosine in myocardial ischemia. Circulation 85, 893-904. doi: 10.1161/01.CIR.85.3.893

Escriche, M., Burgueño, J., Ciruela, F., Canela, E. I., Mallol, J., Enrich, C., et al. (2003). Ligand-induced caveolae-mediated internalization of Al adenosine receptors: morphological evidence of endosomal sorting and receptor recycling. Exp. Cell Res. 285, 72-90. doi: 10.1016/S0014-4827(02)00090-3

Feiner, E. C., Chung, P., Jasmin, J. F., Zhang, J., Whitaker-Menezes, D., Myers, V., et al. (2011). Left ventricular dysfunction in murine models of heart failure and in failing human heart is associated with a selective decrease in the expression of caveolin-3. J. Card. Fail. 17, 253-263. doi: 10.1016/j.cardfail.2010.10.008

Fridolfsson, H. N., and Patel, H. H. (2013). Caveolin-and caveolae in age associated cardiovascular disease. J. Geriatr. Cardiol. 10, 66-74. doi: 10.3969/j.issn.16715411.2013.01.011

Fujimoto, T. (1993). Calcium pump of the plasma membrane is localized in caveolae. J. Cell Biol. 120, 1147-1157. doi: 10.1083/jcb.120.5.1147

Galbiati, F., Volonte, D., Minetti, C., Bregman, D. B., and Lisanti, M. P. (2000). Limb-girdle muscular dystrophy (LGMD-1C) mutants of caveolin-3 undergo ubiquitination and proteasomal degradation. Treatment with proteasomal inhibitors blocks the dominant negative effect of LGMD-1C mutanta and rescues wild-type caveolin-3. J. Biol Chem. 275, 37702-377011. doi: 10.1074/jbc.M006657200

Gazzerro, E., Sotgia, F., Bruno, C., Lisanti, M. P., and Minetti, C. (2010). Caveolinopathies: from the biology of caveolin-3 to human diseases. Eur. J. Hum. Genet. 18, 137-145. doi: 10.1038/ejhg.2009.103

Ghaedi, M., Calle, E. A., Mendez, J. J., Gard, A. L., Balestrini, J., Booth, A., et al. (2013). Human iPS cell-derived alveolar epithelium repopulates lung extracellular matrix. J. Clin. Invest. 123, 4950-4962. doi: 10.1172/JCI68793

Gilks, W. P., Abou-Sleiman, P. M., Gandhi, S., Jain, S., Singleton, A., Lees, A. J., et al. (2005). A common LRRK2 mutation in idiopathic Parkinson's disease. Lancet 365, 415-416. doi: 10.1016/S0140-6736(05)17830-1

Ginés, S., Ciruela, F., Burgueño, J., Casado, V., Canela, E. I., Mallol, J., et al. (2001). Involvement of caveolin-in ligand-induced recruitment and internalization of $\mathrm{A} 1$ adenosine receptor and adenosine deaminase in an epithelial cell line. Mol. Pharmacol. 59, 1314-1323. doi: 10.1124/mol.59.5.1314

Gratton, J. P., Bernatchez, P., and Sessa, W. C. (2004). Caveolae and caveolins in the cardiovascular system. Circ. Res. 94, 1408-1417. doi: 10.1161/01.RES.0000129178.56294.17

Gumbleton, M., Hollins, A. J., Omidi, Y., Campbell, L., and Taylor, G. (2003). Targeting caveolae for vesicular drug transport. J. Control. Release 87, 139-151. doi: 10.1016/S0168-3659(02)00358-9

Guo, J., Wang, T., Li, X., Shallow, H., Yang, T., Li, W., et al. (2012). Cell surface expression of human ether-a-go-go-related gene (hERG) channels is regulated by caveolin-3 protein via the ubiquitin ligase Nedd4-2. J. Biol. Chem. 287, 33132-33141. doi: 10.1074/jbc.M112.389643

Guo, Y., Golebiewska, U., and Scarlata, S. (2011). Modulation of $\mathrm{Ca}^{2}+$ activity in cardiomyocytes through caveolae-Gaq interactions. Biophys. J. 100, 1599-1607. doi: 10.1016/j.bpj.2011.02.013

Gwathmey, J. K., and Morgan, J. P. (1985). Altered calcium handling in experimental pressure-overload hypertrophy in the ferret. Circ. Res. 57, 836-843. doi: 10.1161/01.RES.57.6.836

Hagiwara, Y., Sasaoka, T., Araishi, K., Imamura, M., Yorifuji, H., Nonaka, I., et al. (2000). Caveolin-3 deficiency causes muscle degeneration in mice. Hum. Mol. Genet. 9, 3047-3054. doi: 10.1093/hmg/9.20.3047

Harrison, D. G. (1991). Endothelial modulation of vascular tone: relevance to coronary angioplasty and restenosis. J. Am. Coll. Cardiol. 17(6 Suppl. B), 71B-76B. doi: 10.1016/0735-1097(91)90941-2

Hashimoto, M., Takenouchi, T., Rockenstein, E., and Masliah, E. (2003). Alphasynuclein up-regulates expression of caveolin-1 and down-regulates extracellular signal-regulated kinase activity in B103 neuroblastoma cells: role in the pathogenesis of Parkinson's disease. J. Neurochem. 85, 1468-1479. doi: 10.1046/j.1471-4159.2003.01791.x

Hattori, C., Asai, M., Onishi, H., Sasagawa, N., Hashimoto, Y., Saido, T. C., et al. (2006). BACE1 interacts with lipid raft proteins. J. Neurosci. Res. 84, 912-917. doi: 10.1002/jnr.20981

Head, B. P., Peart, J. N., Panneerselvam, M., Yokoyama, T., Pearn, M. L., Niesman, I. R., et al. (2010). Loss of caveolin-1 accelerates neurodegeneration and aging. PLoS ONE 5:e15697. doi: 10.1371/journal.pone.0015697

Hillion, J., Canals, M., Torvinen, M., Casado, V., Scott, R., Terasmaa, A., et al. (2002). Coaggregation, cointernalization, and codesensitization of adenosine A2A receptors and dopamine D2 receptors. J. Biol. Chem. 277, 18091-18097. doi: $10.1074 /$ jbc.M107731200

Hnasko, R., and Lisanti, M. P. (2003). The biology of caveolae: lessons from caveolin knockout mice and implications for human disease. Mol. Interv. 3, 445-464. doi: 10.1124/mi.3.8.445

Hove-Madsen, L., Llach, A., Bayes-Genis, A., Roura, S., Rodriguez Font, E., Aris, A., et al. (2004). Atrial fibrillation is associated with increased spontaneous calcium release from the sarcoplasmic reticulum in human atrial myocytes. Circulation 110, 1358-1363. doi: 10.1161/01.CIR.0000141296.59876.87

Hove-Madsen, L., Prat-Vidal, C., Llach, A., Ciruela, F., Casadó, V., Lluis, C., et al. (2006). Adenosine A2A receptors are expressed in human atrial myocytes and modulate spontaneous sarcoplasmic reticulum calcium release. Cardiovasc. Res. 72, 292-302. doi: 10.1016/j.cardiores.2006.07.020

Huang, H., Cao, D., Qin, L., Tian, S., Liang, Y., Pan, S., et al. (2014). Dilutionstable PAMAM G1-grafted polyrotaxane supermolecules deliver gene into cells through a caveolae-dependent pathway. Mol. Pharm. 11, 2323-2333. doi: $10.1021 / \mathrm{mp} 5002608$ 
Insel, P. A., Head, B. P., Patel, H. H., Roth, D. M., Bundey, R. A., and Swaney, J. S. (2005). Compartmentation of G-protein-coupled receptors and their signalling components in lipid rafts and caveolae. Biochem. Soc. Trans. 33, 1131-1134. doi: 10.1042/BST20051131

Islam, M. A., Shin, J. Y., Firdous, J., Park, T. E., Choi, Y. J., Cho, M. H., et al. (2012). The role of osmotic polysorbitol-based transporter in RNAi silencing via caveolae-mediated endocytosis and COX-2 expression. Biomaterials 33, 8868-8880. doi: 10.1016/j.biomaterials.2012.08.049

Iwata, A., Maruyama, M., Kanazawa, I., and Nukina, N. (2001). Alphasynuclein affects the MAPK pathway and accelerates cell death. J. Biol. Chem. 276, 45320-45329. doi: 10.1074/jbc.M103736200

Jacob, M. I., and Berne, R. M. (1961). Metabolism of adenosine by the isolated anoxic cat heart. Proc. Soc. Exp. Biol. Med. 107, 738-739. doi: 10.3181/00379727107-26739

Kirschmeier, P. T., Whyte, D., Wilson, O., Bishop, W. R., and Pai, J. K. (2001). In vivo prenylation analysis of Ras and Rho proteins. Meth. Enzymol. 332, 115-127. doi: 10.1016/S0076-6879(01)32196-1

Kitakaze, M., Hori, M., and Kamada, T. (1993). Role of adenosine and its interaction with alpha adrenoceptor activity in ischaemic and reperfusion injury of the myocardium. Cardiovasc. Res. 27, 18-27. doi: 10.1093/cvr/27.1.18

Klaasse, E. C., van den Hout, G., Roerink, S. F., de Grip, W. J., IJzerman, A. P., and Beukers, M. W. (2005). Allosteric modulators affect the internalization of human adenosine A1 receptors. Eur. J. Pharmacol. 522, 1-8. doi: 10.1016/j.ejphar.2005.08.052

Kusama, T., Mukai, M., Iwasaki, T., Tatsuta, M., Matsumoto, Y., Akedo, H., et al. (2001). Inhibition of epidermal growth factor-induced RhoA translocation and invasion of human pancreatic cancer cells by 3-hydroxy-3-methylglutarylcoenzyme a reductase inhibitors. Cancer Res. 61, 4885-4891.

Lam, R. S., Nahirney, D., and Duszyk, M. (2009). Cholesterol-dependent regulation of adenosine A2A receptor-mediated anion secretion in colon epithelial cells. Exp. Cell Res. 315, 3028-3035. doi: 10.1016/j.yexcr.2009.06.005

Lasley, R. D., Narayan, P., Uittenbogaard, A., and Smart, E. J. (2000). Activated cardiac adenosine $\mathrm{A}(1)$ receptors translocate out of caveolae. J. Biol. Chem. 275, 4417-4421. doi: 10.1074/jbc.275.6.4417

Lasley, R. D., and Smart, E. J. (2001). Cardiac myocyte adenosine receptors and caveolae. Trends Cardiovasc. Med. 11, 259-263. doi: 10.1016/S10501738(01)00120-7

Lee, S. J., Liyanage, U., Bickel, P. E., Xia, W., Lansbury, P. T. Jr., and Kosik, K. S. (1998). A detergent-insoluble membrane compartment contains A beta in vivo. Nat. Med. 4, 730-734. doi: 10.1038/nm0698-730

Lei, B., Morris, D. P., Smith, M. P., and Schwinn, D. A. (2009). Lipid rafts constrain basal alpha(1A)-adrenergic receptor signaling by maintaining receptor in an inactive conformation. Cell. Signal. 21, 1532-1539. doi: 10.1016/j.cellsig.2009.06.001

Lerman, A., and Burnett, J. C., Jr. (1992). Intact and altered endothelium in regulation of vasomotion. Circulation 86(Suppl. 6), III12-III19.

Li, S., Okamoto, T., Chun, M., Sargiacomo, M., Casanova, J. E., Hansen, S. H., et al. (1995). Evidence for a regulated interaction between heterotrimeric $\mathrm{G}$ proteins and caveolin. J. Biol. Chem. 270, 15693-15701. doi: 10.1074/jbc.270.26.15693

Lin, J., Lin, S., Choy, P. C., Shen, X., Deng, C., Kuang, S., et al. (2008). The regulation of the cardiac potassium channel (HERG) by caveolin-1. Biochem. Cell Biol. 86, 405-415. doi: 10.1139/O08-118

Llach, A., Molina, C. E., Prat-Vidal, C., Fernandes, J., Casadó, V., Ciruela, F., et al. (2011). Abnormal calcium handling in atrial fibrillation is linked to up-regulation of adenosine A2A receptors. Eur. Heart J. 32, 721-729. doi: 10.1093/eurheartj/ehq464

Massaeli, H., Sun, T., Li, X., Shallow, H., Wu, J., Xu, J., et al. (2010). Involvement of caveolin-in low $\mathrm{K}+$-induced endocytic degradation of cell-surface human ethera-go-go-related gene (hERG) channels. J. Biol. Chem. 285, 27259-27264. doi: 10.1074/jbc.M110.124909

Minetti, C., Sotgia, F., Bruno, C., Scartezzini, P., Broda, P., Bado, M., et al. (1998). Mutations in the caveolin-3 gene cause autosomal dominant limb-girdle muscular dystrophy. Nat. Genet. 18, 365-368. doi: 10.1038/ng0498-365

Minguet, G., Brichant, J. F., and Joris, J. (2012). Opioids and protection against ischemia-reperfusion injury: from experimental data to potential clinical applications. Acta Anaesthesiol. Belg. 63, 23-34.

Monier, S., Parton, R. G., Vogel, F., Behlke, J., Henske, A., and Kurzchalia, T. (1995). VIP21-caveolin, a membrane protein constituent of the caveolar coat, oligomerizes in vivo and in vitro. Mol. Biol. Cell 6, 911-927. doi: 10.1091/mbc.6.7.911
Nishiyama, K., Trapp, B. D., Ikezu, T., Ransohoff, R. M., Tomita, T., Iwatsubo, T., et al. (1999). Caveolin-3 upregulation activates beta-secretase-mediated cleavage of the amyloid precursor protein in Alzheimer's disease. J. Neurosci. 19, 6538-6548.

Oh, P., Horner, T., Witkiewicz, H., and Schnitzer, J. E. (2012). Endothelin induces rapid, dynamin-mediated budding of endothelial caveolae rich in ET-B. J. Biol. Chem. 287, 17353-17362. doi: 10.1074/jbc.M111.338897

Oh, P., and Schnitzer, J. E. (1999). Immunoisolation of caveolae with high affinity antibody binding to the oligomeric caveolin cage. J. Biol. Chem. 274, 23144-23154. doi: 10.1074/jbc.274.33.23144

Ohsawa, Y., Okada, T., Nishimatsu, S., Ishizaki, M., Suga, T., Fujino, M., et al. (2012). An inhibitor of transforming growth factor beta type I receptor ameliorates muscle atrophy in a mouse model of caveolin-3deficient muscular dystrophy. Lab. Invest. 92, 1100-1114. doi: 10.1038/labinvest. 2012.78

Ostrerova, N., Petrucelli, L., Farrer, M., Mehta, M., Choi, P., Hardy, J., et al. (1999). Alpha-synuclein shares physical and functional homology with 14-3-3 proteins. J. Neurosci. 19, 5782-5791.

Palygin, O. A., Pettus, J. M., and Shibata, E. F. (2008). Regulation of caveolar cardiac sodium current by a single Gsalpha histidine residue. Am. J. Physiol. Heart Circ. Physiol. 294, H1693-H1699. doi: 10.1152/ajpheart.01337.2007

Park, D. S., Cohen, A. W., Frank, P. G., Razani, B., Lee, H., Williams, T. M., et al. (2003). Caveolin-1 null (-/-) mice show dramatic reductions in life span. Biochemistry 42, 15124-15131. doi: 10.1021/bi0356348

Park, D. S., Woodman, S. E., Schubert, W., Cohen, A. W., Frank, P. G., Chandra, M., et al. (2002). Caveolin-1/3 double-knockout mice are viable, but lack both muscle and non-muscle caveolae, and develop a severe cardiomyopathic phenotype. Am. J. Pathol. 160, 2207-2217. doi: 10.1016/S0002-9440(10)61168-6

Parton, R. G. (1994). Ultrastructural localization of gangliosides; GM1 is concentrated in caveolae. J. Histochem. Cytochem. 42, 155-166. doi: 10.1177/42.2.8288861

Pavlides, S., Gutierrez-Pajares, J. L., Iturrieta, J., Lisanti, M. P., and Frank, P. G. (2014). Endothelial caveolin-1 plays a major role in the development of atherosclerosis. Cell Tissue Res. 356, 147-157. doi: 10.1007/s00441-013-1767-7

Pelleg, A. (1993). Mechanisms of action and therapeutic potential of adenosine and its analogues in the treatment of cardiac arrhythmias. Coron. Artery Dis. 4, 109-115. doi: 10.1097/00019501-199301000-00010

Phillips, M. I. (2014). Tumor-free iPS stem cells for heart cells. Cell Cycle 13, 1519. doi: $10.4161 /$ cc. 28894

Polymeropoulos, M. H., Lavedan, C., Leroy, E., Ide, S. E., Dehejia, A., Dutra, A., et al. (1997). Mutation in the alpha-synuclein gene identified in families with Parkinson's disease. Science 276, 2045-2047. doi: 10.1126/science.276.5321.2045

Quyyumi, A. A. (1998). Endothelial function in health and disease: new insights into the genesis of cardiovascular disease. Am. J. Med. 105, 32S-39S. doi: 10.1016/S0002-9343(98)00209-5

Razani, B., and Lisanti, M. P. (2001). Two distinct caveolin-1 domains mediate the functional interaction of caveolin-1 with protein kinase A. Am. J. Physiol. Cell Physiol. 281, C1241-C1250.

Rothberg, K. G., Heuser, J. E., Donzell, W. C., Ying, Y. S., Glenney, J. R., and Anderson, R. G. (1992). Caveolin, a protein component of caveolae membrane coats. Cell 68, 673-682. doi: 10.1016/0092-8674(92)90143-Z

Rothberg, K. G., Ying, Y. S., Kamen, B. A., and Anderson, R. G. (1990). Cholesterol controls the clustering of the glycophospholipid-anchored membrane receptor for 5-methyltetrahydrofolate. J. Cell Biol. 111, 2931-2938.

Salmon, A. H., and Satchell, S. C. (2012). Endothelial glycocalyx dysfunction in disease: albuminuria and increased microvascular permeability. J. Pathol. 226, 562-574. doi: 10.1002/path.3964

Sánchez-Felipe, L., Villar, E., and Muñoz-Barroso, I. (2014). Entry of newcastle disease virus into the host cell: role of acidic $\mathrm{pH}$ and endocytosis. Biochim. Biophys. Acta 1838, 300-309. doi: 10.1016/j.bbamem.2013.08.008

Sargiacomo, M., Scherer, P. E., Tang, Z.-L., Kubler, E., Song, K. S., and Sanders, M. C., Lisanti, M. P. (1995). Proc. Natl. Acad. Sci. U.S.A. 92, 9407-9411. doi: 10.1073/pnas.92.20.9407

Scherer, P. E., Okamoto, T., Chun, M., Nishimoto, I., Lodish, H. F., and Lisanti, M. P. (1996). Identification, sequence, and expression of caveolin-2 defines a caveolingene family. Proc. Natl. Acad. Sci. U.S.A. 93, 131-135. doi: 10.1073/pnas.93.1.131

Severs, N. J. (1981). Plasma membrane cholesterol in myocardial muscle and capillary endothelial cells. Distribution of filipin-induced deformations in freeze-fracture. Eur. J. Cell Biol. 25, 289-299. 
Shibata, E. F., Brown, T. L., Washburn, Z. W., Bai, J., Revak, T. J., and Butters, C. A. (2006). Autonomic regulation of voltage-gated cardiac ion channels. J. Cardiovasc. Electrophysiol. 17, S34-S42. doi: 10.1111/j.15408167.2006.00387.x

Shiroto, T., Romero, N., Sugiyama, T., Sartoretto, J. L., Kalwa, H., Yan, Z., et al. (2014). Caveolin-1 is a critical determinant of autophagy, metabolic switching, and oxidative stress in vascular endothelium. PLOS ONE 9:e87871. doi: 10.1371/journal.pone.0087871

Shvets, E., Ludwig, A., and Nichols, B. J. (2014). News from the caves: update on the structure and function of caveolae. Curr. Opin. Cell Biol. 29C, 99-106. doi: 10.1016/j.ceb.2014.04.011

Stary, C. M., Tsutsumi, Y. M., Patel, P. M., Head, B. P., Patel, H. H., and Roth, D. M. (2012). Caveolins: targeting pro-survival signaling in the heart and brain. Front. Physiol. 3:393. doi: 10.3389/fphys.2012.00393

Takeda, A., Mallory, M., Sundsmo, M., Honer, W., Hansen, L., and Masliah, E. (1998). Abnormal accumulation of NACP/alpha-synuclein in neurodegenerative disorders. Am. J. Pathol. 152, 367-372.

Tang, Z., Scherer, P. E., Okamoto, T., Song, K., Chu, C., Kohtz, D. S., et al. (1996). Molecular cloning of caveolin-3, a novel member of the caveolin-gene family expressed predominantly in muscle. J. Biol. Chem. 271, 2255-2261. doi: 10.1074/jbc.271.4.2255

Thomas, S., Overdevest, J. B., Nitz, M. D., Williams, P. D., Owens, C. R., SanchezCarbayo, M., et al. (2011). Src and caveolin-1 reciprocally regulate metastasis via a common downstream signaling pathway in bladder cancer. Cancer Res. 71, 832-841. doi: 10.1158/0008-5472.CAN-10-0730

Toya, Y., Schwencke, C., Couet, J., Lisanti, M. P., and Ishikawa, Y. (1998). Inhibition of adenylyl cyclase by caveolin peptides. Endocrinol. 139, 2025-2031. doi: 10.1210/en.139.4.2025

Trudeau, M. C., Warmke, J. W., Ganetzky, B., and Robertson, G. A. (1995). HERG, a human inward rectifier in the voltage-gated potassium channel family. Science 269, 92-95. Erratum in: Science 1996 272, 1087.

Tsutsumi, Y. M., Kawaraguchi, Y., Niesman, I. R., Patel, H. H., and Roth, D. M. (2010). Opioid-induced preconditioning is dependent on caveolin-3 expression. Anesth. Analg. 111, 1117-1121. doi: 10.1213/ANE.0b013e3181f3351a

Vaidyanathan, R., Vega, A. L., Song, C., Zhou, Q., Tan, B. H., Berger, S., et al. (2013). The interaction of caveolin-3 protein with the potassium inward rectifier channel Kir2.1: physiology and pathology related to long QT syndrome 9 (LQT9). J. Biol. Chem. 288, 17472-17480. doi: 10.1074/jbc.M112.435370

Vatta, M., Ackerman, M. J., Ye, B., Makielski, J. C., Ughanze, E. E., Taylor, E. W., et al. (2006). Mutant caveolin-3 induces persistent late sodium current and is associated with long-QT syndrome. Circulation 114, 2104-2112. doi: 10.1161/CIRCULATIONAHA.106.635268

Vincent, A. M., Callaghan, B. C., Smith, A. L., and Feldman, E. L. (2011). Diabetic neuropathy: cellular mechanisms as therapeutic targets. Nat. Rev. Neurol. 7, 573-583. doi: 10.1038/nrneurol.2011.137

Way, M., and Parton, R. G. (1996). M-caveolin, a muscle-specific caveolin-related protein. FEBS Lett. 378, 108-112. doi: 10.1016/0014-5793(96)82884-5

Wilde, A. A., and Brugada, R. (2011). Phenotypical manifestations of mutations in the genes encoding subunits of the cardiac sodium channel. Circ. Res. 108, 884-897. doi: 10.1161/CIRCRESAHA.110.238469

Williams, T. M., and Lisanti, M. P. (2004). The Caveolin genes: from cell biology to medicine. Ann. Med. 36, 584-595. doi: 10.1080/07853890410018899
Yamada, E. (1955). The fine structure of the gall bladder epithelium of the mouse. J. Biophys. Biochem. Cytol. 1, 445-458. doi: 10.1083/jcb.1.5.445

Yarbrough, T. L., Lu, T., Lee, H. C., and Shibata, E. F. (2002). Localization of cardiac sodium channels in caveolin-rich membrane domains: regulation of sodium current amplitude. Circ. Res. 90, 443-449. doi: 10.1161/hh0402.105177

Ye, B., Balijepalli, R. C., Foell, J. D., Kroboth, S., Ye, Q., Luo, Y. H., et al. (2008). Caveolin-3 associates with and affects the function of hyperpolarization-activated cyclic nucleotide-gated channel 4. Biochemistry 47, 12312-12318. doi: 10.1021/bi8009295

Yellon, D. M., Baxter, G. F., Garcia-Dorado, D., Heusch, G., and Sumeray, M. S. (1998). Ischaemic preconditioning: present position and future directions. Cardiovasc. Res. 37, 21-33. doi: 10.1016/S0008-6363(97)00214-9

Yu, P., Yang, Z., Jones, J. E., Wang, Z., Owens, S. A., Mueller, S. C., et al. (2004). D1 dopamine receptor signaling involves caveolin-2 in HEK-293 cells. Kidney Int. 66, 2167-2180. doi: 10.1111/j.1523-1755.2004.66007.x

Yuan, S. Y., and Rigor, R. R. (eds.). (2010). "Chapter 4: the endothelial barrier,"in Regulation of Endothelial Barrier Function (San Rafael, CA: Morgan \& Claypool Life Sciences).

Zhang, L., Pan, Y., Qin, G., Chen, L., Chatterjee, T. K., Weintraub, N. L., et al. (2014). Inhibition of stearoyl-coA desaturase selectively eliminates tumorigenic Nanog-positive cells: improving the safety of iPS cell transplantation to myocardium. Cell Cycle 13, 762-771. doi: 10.4161/cc.27677

Zhu, L., Schwegler-Berry, D., Castranova, V., and He, P. (2004). Internalization of caveolin-1 scaffolding domain facilitated by Antennapedia homeodomain attenuates PAF-induced increase in microvessel permeability. Am. J. Physiol. Heart Circ. Physiol. 286, H195-H201. doi: 10.1152/ajpheart.00667.2003

Zhu, Y. Z., Xu, Q. Q., Wu, D. G., Ren, H., Zhao, P., Lao, W. G., et al. (2012). Japanese encephalitis virus enters rat neuroblastoma cells via a $\mathrm{pH}$-dependent, dynamin and caveolae-mediated endocytosis pathway. J. Virol. 86, 13407-13422. doi: 10.1128/JVI.00903-12

Zhuang, L., Kim, J., Adam, R. M., Solomon, K. R., and Freeman, M. R. (2005). Cholesterol targeting alters lipid raft composition and cell survival in prostate cancer cells and xenografts. J. Clin. Invest. 115, 959-968. doi: 10.1172/JCI200519935

Conflict of Interest Statement: The authors declare that the research was conducted in the absence of any commercial or financial relationships that could be construed as a potential conflict of interest.

Received: 01 July 2014; accepted: 08 September 2014; published online: 30 September 2014.

Citation: Navarro G, Borroto-Escuela DO, Fuxe K and Franco R (2014) Potential of caveolae in the therapy of cardiovascular and neurological diseases. Front. Physiol. 5:370. doi: 10.3389/fphys.2014.00370

This article was submitted to Membrane Physiology and Membrane Biophysics, a section of the journal Frontiers in Physiology.

Copyright (c) 2014 Navarro, Borroto-Escuela, Fuxe and Franco. This is an openaccess article distributed under the terms of the Creative Commons Attribution License (CC BY). The use, distribution or reproduction in other forums is permitted, provided the original author(s) or licensor are credited and that the original publication in this journal is cited, in accordance with accepted academic practice. No use, distribution or reproduction is permitted which does not comply with these terms. 